\title{
LİSANS ÖĞRENCİLERİNİN SÜT TÜKETİM ALIŞKANLIKLARININ VE DAVRANIŞLARININ BELİRLENMESİ
}

\author{
Murat Emre Terzioğlu', İhsan Bakırcı \\ Atatürk Üniversitesi, Ziraat Fakültesi, Gıda Mühendisliği Bölümü, Erzurum, Türkiye
}

Geliş / Received: 03.08.2018; Kabul / Accepted: 22.01.2019; Online bask1 / Published online: 22.02.2019

Terzioğlu, M. E., Bakırcı, İ. (2019). Lisans öğrencilerinin süt tüketim alışkanlıklarının ve davranışlarının belirlenmesi. GIDA (2019) 44 (1): 163-172 doi: 10.15237/gida.GD18080

Terzioğlu, M. E., Bakırc1, İ. (2019). Determination of milk consumption habits and behaviors of undergraduate students. GIDA (2019) 44 (1): 163-172 doi: 10.15237/gida.GD18080

\section{ÖZ}

Bu araştırmada, 2016-2017 eğitim-öğretim yllında Erzincan Üniversitesi’nin Eğitim Fakültesi, Fen Edebiyat Fakültesi, İktisadi ve İdari Bilimler Fakültesi, Mühendislik Fakültesi ve Sağlık Bilimleri Fakültesinde öğrenim gören 400 öğrenciye anket uygulanarak elde edilen verilerin kullanılmasılla öğrencilerin süt tüketim alışkanlıkları ve davranışlanı incelenmiştir. Araştırmaya katılan öğrenciler ana kitle oranlarına dayalı kümelendirilmemiş tek aşamalı tesadüfi olasılık örnekleme yöntemi ile belirlenmiştir. Anket sonucunda elde edilen veriler tablolar halinde verilmiştir. Araştırmada öğrencilerin \%67'sinin sütü sevdiği, haftalık kişi başına yaklaşı1 1.3 litre süt tükettiği, bunun gelişmiş ülkelere oranla yeterli olmadığı belirlenmiştir. Öğrencilerin süt satın alırken bakkal ve pazarların yerine genellikle marketleri tercih ettiği ve markaya, fiyata, üretim ve son kullanma tarihine dikkat ettiği görülmüştür. Sağlık Bilimleri Fakültesi öğrencileri haricinde diğer öğrencilerin genellikle süt ile bulaşan hastalıklar konusunda yeterli bilgiye sahip olmadığı belirlenmiştir. Öğrencilerin süt tüketmede ilk sebep olarak sütün besleyici özelliğini ön plana çıkardığı, genel olarak süt tüketiminde herhangi bir sorunla karşılaşmadığı görülmüştür.

Anahtar kelimeler: Süt, süt tüketim alıskkanlıkları, lisans öğrencileri

\section{DETERMINATION OF MILK CONSUMPTION HABITS AND BEHAVIORS OF UNDERGRADUATE STUDENTS}

\begin{abstract}
In this study, a questionnaire to 400 students studying at Faculty of Education, Faculty of Arts and Sciences, Faculty of Economics and Administrative Sciences, Faculty of Engineering and faculty of Health Sciences in Erzincan University in 2016-2017 academic year was applied and the students' milk consumption habits and behaviors were investigated through the obtained data. Students participating in the study were identified by a single, unclustered random probability sampling method based on population ratios. The data obtained through the questionnaire are given in tables. It was determined that $67 \%$ of the students in the survey liked milk, consumed about 1.3 liters of milk per week, which is not enough compared to developed countries. It has been seen that students prefer to supermarkets instead of groceries and shops when buying milk and pay attention to brand, price, production and expiry date. It has been determined that other students, except for the students of the Faculty of Health Sciences, generally do not have enough knowledge about milk-borne diseases. We determined that the first reason of milk consumption is the students were aware of milk having nutritional function and did not encounter any problems in milk consumption in general.
\end{abstract}

Keywords: Milk, milk consumption habits, undergraduate students

\footnotetext{
* Yazışmalardan sorumlu yazar/Corresponding author
}

? murat.terzioglu@atauni.edu.tr (c) (+90) 4422312485

(+90) 4422360958 


\section{GİRİ̧}

Bu çalışma, Erzincan Üniversitesi'ndeki çeşitli fakültelerde öğrenim gören öğrencilerin, çeşitli parametreler göz önünde bulundurularak süt tüketim alışkanlıklarını, bu alışkanlıkları etkileyen faktörleri ve süt tüketimi hakkındaki bilgi düzeylerini belirlemek amacıyla yapılmıştır. $\mathrm{Bu}$ kapsamda üniversite öğrencilerinin süt tüketim alışkanlıklarının ve bu konudaki bilgi düzeylerinin ortaya konması ve elde edilen bu veriler doğrultusunda üniversite öğrencilerinin süt tüketimi konusunda bilinçlendirilmesi, karşılaştıkları sorunların belirlenmesi, sorunlara dair gerekli önlemlerin alınması, süt tüketimini arttırıcı çözüm önerilerinin sunulması ve bu sayede daha sağlıklı bireyler için atılacak adımlara zemin oluşturulması bakımından önem taşımaktadır.

Beslenmede temel gida maddesi olarak kabul edilen süt; yaşamın her evresinde gerekli olup, yeterli ve dengeli beslenmenin sağlanmasında, enerji alınımında, kemik sağlığının korunmasında, obezite, kanser ve hipertansiyon gibi kronik hastalıkların önlenmesinde önemli bir faktördür (Tönük vd., 1984; Arabacıoğlu Özbilen, 1993; Christopher ve Nordin, 1997; Jain, 1998; Heaney vd., 1999; Miller vd., 2000; Black vd., 2002; Weinberg vd., 2004; Ünal ve Besler, 2008). Süt, zengin besin içeriği (protein, kalsiyum, fosfor, $\mathrm{A}$, $B_{2}$ ve $B_{12}$ vitamini) yönüyle ön plana çıkmakta (Ünal ve Besler, 2008; Biyıklı, 2011) ve doğada kazein, laktoz, süt yağı, $\alpha$-laktalbumin ve $\beta$ laktoglobulin sadece sütte bulunmaktadır (Metin, 2014). Bünyesinde yer alan esansiyel aminoasitler vasitasiyla bilhassa çocuklarda büyüme ve gelişmeyi arttırmakta, galaktoz vasıtasıyla beyin hücrelerinin gelişimini sağlamakta ve kalsiyum vasıtasıyla kemik sağlığının korunmasında önemli bir rol oynamaktadır (Çapraz ve Yilmaz, 2005; Biyıkl1, 2011).

Süt, beslenmede bu denli önemli bir gida olmasina rağmen ülkemizdeki tüketim oranları gelişmiş ülkelere oranla düşük seviyelerde bulunmakta, kişi başına yıllık süt tüketim miktarı $\mathrm{AB}$ ülkelerinde 89 kg, ABD'de $83 \mathrm{~kg}$ ve Avustralya'da $107 \mathrm{~kg}$ iken, Türkiye'de $26 \mathrm{~kg}$ olduğu bildirilmektedir (Asüd, 2010).
Öğrencilere erken yaşlardan itibaren süt tüketim alışkanlığı kazandırmak amacıyla ilk olarak 20112012 eğitim öğretim yllında uygulanmaya başlayan Okul Sütü Programı kapsamında 1. yıl Türkiye genelinde 136 milyondan fazla kutu süt, 2. yıl ülke genelindeki bütün ilkokullara yayılarak yaklaşı 296 milyondan fazla kutu süt dağıtımı yapılmıştır. 9 Şubat 2015'ten itibaren ise yaklaşı 34 bin okulda haftada 3 gün (Pazartesi, Çarşamba, Cuma) olmak üzere güvenilir ve sağlıklı ambalajlarda süt dağıtımı gerçekleşmektedir. Okul Sütü Programı, AB üyesi 26 ülkede (Yunanistan ve Hirvatistan hariç) 2011-2012 yllları arasında, Rusya'da 2005'te, Çin'de ise 2000 yllinda uygulanmaya başlamıştır (Anonymous, 2018).

\section{MATERYAL VE YÖNTEM}

Bu araştırmada 2016-2017 eğitim-öğretim yllında Erzincan Üniversitesi Eğitim Fakültesi, Fen Edebiyat Fakültesi, İktisadi ve İdari Bilimler Fakültesi, Mühendislik Fakültesi ve Sağlık Bilimleri Fakültesinde öğrenim gören öğrencilerden örnekleme yöntemiyle 400 kişi seçilmiştir. Örnek hacmi, ana kitle oranlarına dayalı kümelendirilmemiş tek aşamalı tesadüfi olasillk örnekleme yöntemi ile belirlenmiştir (Collins, 1986). Seçilen bu öğrencilere anket formu dağıtılarak ve gerekli açıklamalar yapılarak anketi doldurmaları istenmiştir. Anket çalışması ile elde edilen veriler bilgisayar ortamında SPSS 20 paket programı (IBM SPSS Statistics for Windows, Version 20.0, USA) ve istatistiksel analiz olarak Ki-Kare testi (Şahinöz ve Özdemir, 2017) ile analiz edilmiştir. Elde edilen bulgular tablolar haline getirilerek yorumlanmıştır.

\section{BULGULAR VE TARTIŞMA}

Erzincan Üniversitesi lisans öğrencilerinin süt tüketim alışkanlıklarının ve davranışlarının belirlenmesi konulu anket çalışması için tesadüfi örnekleme yöntemi ile seçilen 400 öğrencinin anket sorularına verdiği cevapların yüzde ve frekans dağılımları Çizelge 1-Çizelge 7'de gösterilmektedir.

Öğrencilere "süt içmeyi seviyor musunuz?" sorusu yöneltilmiştir. Öğrencilerin \%67'si süt içmeyi sevdiğini belirtmiştir. Ayar ve Demirulus 
(2000) eğitim çağındaki gençlerin süt ve süt ürünleri tüketim alışkanlıklarını araştırdıkları çalışmada, öğrencilerin \%80'inin süt içmeyi sevdiğini belirlemişlerdir. Durmaz vd. (2002) Yüzüncü Y1l Üniversitesi Yüksekokul öğrencilerinin içme sütü tüketim alışkanlıkları üzerine yaptıkları çalışmada, öğrencilerin $\%$ 77.41'inin süt içmeyi sevdiğini ortaya koymuşlardır. Tarakçı vd. (2003) Yüzüncü Y1l Üniversitesi lisans öğrencilerinin içme sütü tüketim alışkanlıklarını inceledikleri çalısmada, öğrencilerin \%78.96'sının süt içmeyi sevdiğini saptamışlardır. Şimşek ve Açıgöz (2011) Süleyman Demirel Üniversitesi öğrencilerinin içme sütü tüketim alışkanlıkları üzerine yaptıkları çalışmada, öğrencilerin \%69.7'sinin süt içmeyi sevdiğini belirtmişlerdir. Yapılan çalışmalarla bu anket çalışması sonuçlarının benzerlik gösterdiği tespit edilmiştir.

Çizelge 1. Katılımcıların "Fakülteniz" sorusuna vermiş olduğu cevapların yüzde ve frekans dağılımları

Table 1. Percentages and frequency distributions of participants' responses to the question of "What is your Faculty?"

\begin{tabular}{|l|c|c|}
\cline { 2 - 3 } \multicolumn{1}{c|}{$\begin{array}{l}\text { Eğitim Fakültesi / } \\
\text { Faculty of Education }\end{array}$} & Frekans / Frequency & Yüzde / Percent \\
\hline $\begin{array}{l}\text { Fen Edebiyat } \\
\text { Faculty of Arts and Sciences }\end{array}$ & 81 & 20.3 \\
\hline $\begin{array}{l}\text { İktisadi ve İdari Bilimler Fakültesi / } \\
\text { Faculty of Economics and Administrative Sciences }\end{array}$ & 80 & 20.0 \\
\hline $\begin{array}{l}\text { Mühendislik Fakültesi / Faculty of Engineering } \\
\text { Sağllk Bilimleri Fakültesi / Faculty of Health Sciences }\end{array}$ & 79 & 19.8 \\
\hline Toplam / Total & 80 & 20.0 \\
\hline
\end{tabular}

Çizelge 2. Fakülteye göre katılımcıların "Süt içmeyi seviyor musunuz?" sorusuna verdikleri cevapların frekans ve yüzde dağılımları

Table 2. Frequency and percentage distributions of respondents, according to the faculty, to the question of "Do you like to drink milk?"

\begin{tabular}{|l|l|c|c|c|}
\cline { 5 - 5 } \multicolumn{2}{l|}{} & Evet / Yes & Haylr / No & Toplam / Total \\
\hline $\begin{array}{l}\text { Eğitim Fakültesi / } \\
\text { Faculty of Education }\end{array}$ & $\begin{array}{l}\text { Fakülte içinde } \\
\text { / In faculty } \%\end{array}$ & $\% 76.5$ & $\% 23.5$ & $\% 100.0$ \\
\hline $\begin{array}{l}\text { Fen Edebiyat Fakültesi / } \\
\text { Faculty of Arts and Sciences }\end{array}$ & $\begin{array}{l}\text { Fakülte içinde } \\
/ \text { In faculty } \%\end{array}$ & $\% 66.2$ & $\% 33.8$ & $\% 100.0$ \\
\hline $\begin{array}{l}\text { İktisadi ve İdari Bilimler Fakültesi / } \\
\text { Faculty of Economics and Administrative Sciences }\end{array}$ & $\begin{array}{l}\text { Fakülte içinde } \\
\text { / In faculty } \%\end{array}$ & $\% 55.7$ & $\% 44.3$ & $\% 100.0$ \\
\hline $\begin{array}{l}\text { Mühendislik Fakültesi / Faculty of } \\
\text { Engineering }\end{array}$ & $\begin{array}{l}\text { Fakülte içinde } \\
\text { / In faculty } \%\end{array}$ & $\% 68.8$ & $\% 31.2$ & $\% 100.0$ \\
\hline $\begin{array}{l}\text { Sağllk Bilimleri Fakültesi / Faculty of Health } \\
\text { Sciences }\end{array}$ & $\begin{array}{l}\text { Fakülte içinde } \\
\text { / In faculty } \%\end{array}$ & $\% 67.5$ & $\% 32.5$ & $\% 100.0$ \\
\hline $\begin{array}{l}\text { Toplam / Total } \\
\text { Fakülte içinde } \\
\text { / In faculty } \%\end{array}$ & $\% 67.0$ & $\% 33.0$ & $\% 100.0$ \\
\hline
\end{tabular}


Çizelge 3. Fakülteye göre katılımcıların "Haftalık ortalama ne kadar süt tüketiyorsunuz?” sorusuna verdikleri cevapların frekans ve yüzde dağılımları

Table 3. Frequency and percentage distributions of respondents, according to the faculty, to the question of "How much milk do you consume in average weekly?"

\begin{tabular}{|c|c|c|c|c|c|c|}
\hline & & $\begin{array}{c}1 \\
\text { LT'nin } \\
\text { alt1 / } \\
\text { under } 1 \\
\text { LT } \\
\end{array}$ & $\begin{array}{c}1-2 \mathrm{LT} \\
\text { aras1 / } \\
\text { between } \\
1 \mathrm{LT}-2 \\
\mathrm{LT} \\
\end{array}$ & $\begin{array}{c}\text { 2-4 LT } \\
\text { aras1 / } \\
\text { between } 2 \\
\text { LT-4 } \\
\text { LT } \\
\end{array}$ & $\begin{array}{l}4 \text { LT ve } \\
\text { üzeri / } \\
\text { over } 4 \\
L T\end{array}$ & $\begin{array}{c}\text { Toplam / } \\
\text { Total }\end{array}$ \\
\hline $\begin{array}{l}\text { Eğitim Fakültesi / } \\
\text { Faculty of Education }\end{array}$ & $\begin{array}{l}\text { Fakülte içinde } \\
\text { / In faculty } \%\end{array}$ & $\% 24.7$ & $\% 42.0$ & $\% 29.6$ & $\% 3.7$ & $\% 100.0$ \\
\hline $\begin{array}{l}\text { Fen Edebiyat Fakültesi / } \\
\text { Faculty of Arts and Sciences }\end{array}$ & $\begin{array}{l}\text { Fakülte içinde } \\
\text { / In faculty } \%\end{array}$ & $\% 22.5$ & $\% 52.5$ & $\% 18.8$ & $\% 6.2$ & $\% 100.0$ \\
\hline $\begin{array}{l}\text { İktisadi ve İdari Bilimler Fakültesi } \\
\text { / Faculty of Economics and } \\
\text { Administrative Sciences }\end{array}$ & $\begin{array}{l}\text { Fakülte içinde } \\
\text { / In faculty } \%\end{array}$ & \%41.8 & $\% 44.3$ & $\% 8.9$ & $\% 5.1$ & $\% 100.0$ \\
\hline $\begin{array}{l}\text { Mühendislik Fakültesi / } \\
\text { Faculty of Engineering }\end{array}$ & $\begin{array}{l}\text { Fakülte içinde } \\
\text { / In faculty \% }\end{array}$ & $\% 35.0$ & $\% 30.0$ & $\% 30.0$ & $\% 5.0$ & \%100.0 \\
\hline $\begin{array}{l}\text { Sağllk Bilimleri Fakültesi / } \\
\text { Faculty of Health Sciences }\end{array}$ & $\begin{array}{l}\text { Fakülte içinde } \\
\text { / In faculty } \%\end{array}$ & $\% 37.5$ & $\% 41.2$ & $\% 18.8$ & $\% 2.5$ & $\% 100.0$ \\
\hline Toplam / Total & $\begin{array}{l}\text { Fakülte içinde } \\
\text { / In faculty \% }\end{array}$ & $\% 32.2$ & $\% 42.0$ & $\% 21.2$ & $\% 4.5$ & $\% 100.0$ \\
\hline
\end{tabular}

Öğrencilere "haftalık ortalama ne kadar süt tüketiyorsunuz?" sorusu yöneltilmiştir. Öğrencilerin \%74.2'sinin haftalık 2 litreden daha az süt tükettiği görülmüştür. Tüm fakültelerde 4 litrenin üstünde süt tüketen öğrencilerin oranının $\% 4.5$ gibi düşük seviyelerde olduğu saptanmıştır. Karagözlü vd. (2005) Celal Bayar Üniversitesi Mühendislik Fakültesi öğrencilerinde süt ve ürünleri tüketim alışkanlıkları ve beslenme bilinçleri üzerine yaptıkları araştırmada, ögrencilerin \%53.09'unun haftada 1-3 litre süt içtiğini belirtmişlerdir. $\mathrm{Bu}$ anket çalışması, Karagözlü vd. (2005)'in bulgularıyla aynı doğrultuda sonuçlanmıștır. Cevger vd. (2008) Ankara Üniversitesi Veteriner Fakültesi intern öğrencilerinde hayvansal ürünlerin tüketim durumunu inceledikleri araştırmada, öğrencilerin kişi başına aylık ortalama 4 litre süt tükettiğini belirlemişlerdir. Çetinkaya (2010) Kafkas Üniversitesi öğrencilerinin içme sütü ve süt ürünlerini tüketim alışkanlıkları üzerine yapmış olduğu çalışmasında, öğrencilerin \%25’inin günlük 1 bardak, $\% 5$ 'inin günlük 2 bardak, \%3'ünün 3 bardak içtiğini, \%67'sinin hiç süt tüketmediğini ortaya koymuştur. Uzunöz ve
Gülşen (2007)'nin Gaziosmanpaşa Üniversitesi öğrencilerinin süt ve süt ürünleri tüketim alışkanlıklarının belirlenmesi üzerine yaptıkları çalıșmada, öğrencilerden \%28.67’sinin, Șimșek ve Açıkgöz (2011)'in yaptığı çalışmada ise öğrencilerden \%34.2'sinin sütü düzenli olarak tükettiğini saptamışlardır. Stefanikova vd. (2006) tıp fakültesi öğrencilerine uyguladığ1 anket çalışmasında öğrencilerin günlük ortalama 230 gram süt tükettiğini saptamışlardır. Manaf vd. (2012) ise çalışmasında süt tüketiminin öğrencilerin \%87.3'ünde düşük seviyelerde (süt tüketiminin haftada 1-3 kere veya daha az) olduğunu belirlemişlerdir. Bu anket çalışmasında, üniversite öğrencilerinin ülke geneline k1yasla daha fazla süt tükettiği görülmektedir. Bunun başlıca nedenleri arasında eğitim düzeyi ve öğrenciye özgü günlük yaşam koşullarının etkileri olduğu söylenebilir. Gelişmiş ülkelerle kıyaslandığında ise öğrencilerin süt tüketim oranlarının istenilen seviyelerde olmadığ1 tespit edilmiştir. Yapılan çalışmalarla anket çalışmamız arasındaki farklılık ise sorularda kullanılan farklı parametrelerden kaynaklanmaktadır. 
Çizelge 4. Fakülteye göre katılımcıların "Sütü nereden alıyorsunuz?" sorusuna verdikleri cevapların frekans ve yüzde dağılımları

Table 4. Frequency and percentage distributions of respondents, according to the faculty, to the question of "Where do you

\begin{tabular}{|c|c|c|c|c|c|c|c|}
\hline & & $\begin{array}{c}\text { Market / } \\
\text { Market }\end{array}$ & $\begin{array}{c}\text { Bakkal / } \\
\text { Shop }\end{array}$ & $\begin{array}{l}\text { Pazar / } \\
\text { Bazaar }\end{array}$ & $\begin{array}{r}\text { Kantin / } \\
\text { Canteen } \\
\end{array}$ & $\begin{array}{l}\text { Diğer / } \\
\text { Other }\end{array}$ & $\begin{array}{c}\text { Toplam / } \\
\text { Total } \\
\end{array}$ \\
\hline $\begin{array}{l}\text { Eğitim Fakültesi / } \\
\text { Faculty of Education }\end{array}$ & $\begin{array}{l}\text { Fakülte } \\
\text { içinde / In } \\
\text { faculty } \%\end{array}$ & $\% 67.9$ & $\% 2.5$ & $\% 0.0$ & $\% 4.9$ & $\% 24.7$ & $\% 100.0$ \\
\hline $\begin{array}{l}\text { Fen Edebiyat } \\
\text { Fakültesi / Faculty of } \\
\text { Arts and Sciences }\end{array}$ & $\begin{array}{l}\text { Fakülte } \\
\text { içinde / In } \\
\text { faculty } \%\end{array}$ & $\% 47.5$ & $\% 7.5$ & $\% 2.5$ & $\% 12.5$ & $\% 30.0$ & $\% 100.0$ \\
\hline $\begin{array}{l}\text { İktisadi ve İdari } \\
\text { Bilimler Fakültesi / } \\
\text { Faculty of Economics and } \\
\text { Administrative Sciences }\end{array}$ & $\begin{array}{l}\text { Fakülte } \\
\text { içinde / In } \\
\text { faculty } \%\end{array}$ & $\% 49.4$ & $\% 6.3$ & $\% 1.3$ & $\% 11.4$ & $\% 31.6$ & $\% 100.0$ \\
\hline $\begin{array}{l}\text { Mühendislik Fakültesi } \\
\text { / Faculty of Engineering }\end{array}$ & $\begin{array}{l}\text { Fakülte } \\
\text { içinde / In } \\
\text { faculty \% }\end{array}$ & $\% 51.2$ & $\% 15.0$ & $\% 3.8$ & $\% 11.2$ & $\% 18.8$ & $\% 100.0$ \\
\hline $\begin{array}{l}\text { Sağlık Bilimleri } \\
\text { Fakültesi / Faculty of } \\
\text { Health Sciences }\end{array}$ & $\begin{array}{l}\text { Fakülte } \\
\text { içinde / In } \\
\text { faculty } \%\end{array}$ & $\% 63.8$ & $\% 1.2$ & $\% 2.5$ & \%18.8 & $\% 13.8$ & $\% 100.0$ \\
\hline Toplam / Total & $\begin{array}{l}\text { Fakülte } \\
\text { içinde / In } \\
\text { faculty } \%\end{array}$ & $\% 56.0$ & $\% 6.5$ & $\% 2.0$ & $\% 11.8$ & $\% 23.8$ & $\% 100.0$ \\
\hline
\end{tabular}

Öğrencilere "sütü nerden alıyorsunuz?" sorusu yöneltilmiştir. Öğrencilerin \%56'sının sütü marketten aldığ 1 belirlenmiștir. Ayrıca, Mühendislik Fakültesinde okuyan öğrencilerin diğer fakültelerde okuyan öğrencilere oranla süt alırken bakkalı daha çok tercih ettiği ve Sağlık Bilimleri Fakültesinde okuyan öğrencilerin diğer fakültelerde okuyan öğrencilere oranla "diğer" seçeneğini daha az tercih ettiği görülmüştür $(\chi 2=36.805, \operatorname{sd}=16, P=0.002)$. Durmaz vd. (2002) yaptıkları çalışmada öğrencilerin \%57.06'sının, Tarakçı vd. (2003) öğrencilerin $\%$ 60.64'ünün sütü marketten aldığını ortaya koymuşlardır. Durmaz vd. (2002) ve Tarakçı vd. (2003)'ün yaptıkları çalışmalarla bu anket çalışması sonuçları benzerlik göstermektedir. Uzunöz ve Gülşen (2007) yaptıkları çalışmada süt ve süt ürünleri alırken öğrencilerin \%93.33'ünün marketi, Cevger vd. (2008) ise süt alırken öğrencilerin \%95.1'inin süpermarketi tercih etiğini belirtmişlerdir. Şeker vd. (2012) Elazığ ili merkez ilçede yapmış oldukları çalışmada, üniversite mezunlarının \% 76.2'sinin süt satın alırken marketi tercih ettiğini saptamışlardır. Uzunöz ve Gülșen (2007), Cevger vd. (2008) ve Şeker vd. (2012)'nin bulguları bu anket çalışması sonuçlarıyla kıyaslandığında marketi tercih eden öğrencilerin oranının çok daha yüksek olduğu görülmektedir. Hasipek vd. (1988) Konya Selçuk Üniversitesi Ziraat Fakültesi öğrencilerinin süt ve süt ürünleri tüketim sıklı̆̆1 ve bunu etkileyen faktörler üzerine yapmış oldukları çalışmada, öğrencilerin \%50'sinin sütü sokak sütçülerinden temin ettiğini belirtmişlerdir. Yapmış olduğumuz bu çalışma ve yakın dönemde literatürde yer alan diğer çalışmalar, Hasipek vd. (1988)'in yapmış olduğu anket çalışmasıyla kıyaslandığında zamana bağlı olarak öğrencilerin süt satın alma konusunda bilinçlendiği, marketlerde eskiye oranla içme sütünün daha fazla yer aldığı ve günümüzde sokak sütçüleri yerine marketlerin daha fazla tercih edildiği görülmektedir.

Öğrencilere "süt alırken markaya dikkat eder misiniz?” sorusu yöneltilmiştir. Öğrencilerin \%79.2'si evet, \%20.8'i hayır yanıtını vermiştir. 
Topcu (2006) Erzurum ilinde süt ürünlerindeki marka rekabeti ve tüketici davranışlarını araştırdığı çalışmasında, süt satın alırken \%35.64'lük oranla en çok markaya dikkat edildiğini saptamıştır. Öğrencilerin Uzunöz ve Gülşen (2007) \%70.33'ünün, Çetinkaya (2010) \%74.5'inin ve Şeker vd. (2012) \%83.6'sının süt satın alırken markaya dikkat ettiğini ortaya koymuşlardır. Yine Yabanc1 Ayhan vd. (2018) üniversite öğrencilerinin süt ve süt ürünleri tüketimi üzerine yaptıkları araştırmada süt satın alırken öğrencilerin \%75.9'unun markaya dikkat ettiğini belirtmişlerdir. Yapılan çalışmalarla araştırma bulgularımızın uyumlu olduğu görülmektedir.

Öğrencilere "süt tüketiminizi fiyatlar etkiler mi?" sorusu yöneltilmiştir. Öğrencilerin \%55.8’i evet, \%44.2'si hayır yanıtını vermiştir. Literatürdeki anket çalışmalarında, Durmaz vd. (2002) öğrencilerin \%51.42'sinin süt fiyatlarını pahalı bulduğunu belirtirken, öğrencilerin Uzunöz ve Gülşen (2007) \%80’inin, Şimşek ve Açıkgöz (2011) \%68.3’ünün, Şeker vd. (2012) \%52.4’ünün,
Şahinöz ve Özdemir (2017) ise \%61.8'inin süt fiyatlarını uygun bulduğunu saptamışlardır. $\mathrm{Bu}$ anket çalışması ve literatürde yer alan diğer çalışmalar, öğrenciler için fiyatların süt tüketiminde önemli bir etken olduğunu ortaya koymakta, farkllik ise sorularda kullanilan parametrelerden kaynaklanmaktadır.

Öğrencilere "süt satın alırken üretim ve son kullanma tarihine dikkat eder misiniz?" sorusu yöneltilmiştir. Öğrencilerin \%89.2'si evet, \%10.8’i hayır yanıtını vermiştir. Öğrencilerin Uzunöz ve Gülşen (2007) \%85'inin, Şeker vd. (2012) \%90.3'ünün ve Para vd. (2018) \%93.5'inin son kullanma tarihine dikkat ettiğini ortaya koymuşlardır. Aynı zamanda öğrencilerin Şimşek ve Açıkgöz (2011) \%39.4'ünün, Şahinöz ve Özdemir (2017) \%49.5'inin süt satın alırken dikkat ettiği en önemli unsurun son kullanma tarihi olduğunu belirlemişlerdir. $\mathrm{Bu}$ anket çalışması, yapılan çalışmalarla aynı doğrultuda olduğu görülmektedir.

Çizelge 5. Fakülteye göre katılımcıların "Süt ile bulaşan hastalıklar hakkında bilginiz var mı?" sorusuna verdikleri cevapların frekans ve yüzde dağılımları

Table 5. Frequency and percentage distributions of respondents, according to the faculty, to the question of "Do you know about milk-borne diseases?"

\begin{tabular}{|l|l|c|c|c|}
\cline { 5 - 5 } \multicolumn{2}{l|}{} & Evet / Yes & Hayır / No & Toplam / Total \\
\hline $\begin{array}{l}\text { Eğitim Fakültesi / } \\
\text { Faculty of Education }\end{array}$ & $\begin{array}{l}\text { Fakülte içinde } \\
\text { / In faculty } \%\end{array}$ & $\% 14.8$ & $\% 85.2$ & $\% 100.0$ \\
\hline $\begin{array}{l}\text { Fen Edebiyat Fakültesi / } \\
\text { Faculty of Arts and Sciences }\end{array}$ & $\begin{array}{l}\text { Fakülte içinde } \\
\text { / In faculty } \%\end{array}$ & $\% 18.8$ & $\% 81.2$ & $\% 100.0$ \\
\hline $\begin{array}{l}\text { İktisadi ve İdari Bilimler Fakültesi / } \\
\text { Faculty of Economics and Administrative Sciences }\end{array}$ & $\begin{array}{l}\text { Fakülte içinde } \\
\text { / In faculty } \%\end{array}$ & $\% 19.0$ & $\% 81.0$ & $\% 100.0$ \\
\hline $\begin{array}{l}\text { Mühendislik Fakültesi / } \\
\text { Faculty of Engineering }\end{array}$ & $\begin{array}{l}\text { Fakülte içinde } \\
\text { / In faculty } \%\end{array}$ & $\% 15.0$ & $\% 85.0$ & $\% 100.0$ \\
\hline $\begin{array}{l}\text { Sağllk Bilimleri Fakültesi / } \\
\text { Faculty of Health Sciences }\end{array}$ & $\begin{array}{l}\text { Fakülte içinde } \\
\text { / In faculty } \%\end{array}$ & $\% 65.0$ & $\% 35.0$ & $\% 100.0$ \\
\hline Toplam / Total & $\begin{array}{l}\text { Fakülte içinde } \\
\text { / In faculty } \%\end{array}$ & $\% 26.5$ & $\% 73.5$ & $\% 100.0$ \\
\hline
\end{tabular}

Öğrencilere "süt ile bulaşan hastalıklar hakkında bilginiz var mı?" sorusu yöneltilmiştir. Sağlık Bilimleri Fakültesinde okuyan öğrencilerin Eğitim
Fakültesi, Fen Edebiyat Fakültesi, İktisadi ve İdari Bilimler Fakültesi ve Mühendislik Fakültesinde okuyan öğrencilere oranla süt ile bulaşan 
hastalıklar hakkında beklendiği gibi daha bilgili ve bilinçli olduğu görülmüştür $(\chi 2=76.747, \mathrm{sd}=4, P$ $=0.000)$. Bu durum, Sağlık Bilimleri Fakültesi müfredatında gıda hijyeni ve sanitasyonu ile ilgili derslerin bulunmasindan kaynaklanmaktadır. Genel olarak ise ankete katılan öğrencilerin \%73.5'inin süt ile bulaşan hastalıklar hakkında bilgisinin olmadığı saptanmıştır. Çetinkaya (2010) yaptığ1 çalışmada, öğrencilerin \%57'sinin süt ve süt ürünleriyle bulaşan hastalıklar konusunda bilgi sahibi olduğunu belirtmiştir. Çetinkaya (2010)'un süt ile bulaşan hastalıklar konusundaki bulguları ile çalışmamıza ait sonuçlar önemli ölçüde farklılık arz etmektedir.

Çizelge 6. Fakülteye göre katılımcıların “Süt tüketmede ilk sebebiniz nedir?” sorusuna verdikleri cevapların frekans ve yüzde dağılımları

Table 6. Frequency and percentage distributions of respondents, according to the faculty, to the question of "What is your

\begin{tabular}{|c|c|c|c|c|c|c|c|c|}
\hline & & $\begin{array}{c}\text { Besleyici } \\
\text { olmasi } \\
\text { /Nutricious }\end{array}$ & $\begin{array}{l}\text { Alış- } \\
\text { kanlık } \\
\text { /Habit }\end{array}$ & $\begin{array}{l}\text { Lezzet/ } \\
\text { Deliciousy }\end{array}$ & $\begin{array}{c}\text { Büyüklerin } \\
\text { zorlamas1 } \\
\text { /Forced by } \\
\text { parents }\end{array}$ & \begin{tabular}{|c|} 
Hastalık \\
duru- \\
munda \\
tedavi \\
amaçli \\
/For \\
bealing \\
purpose \\
\end{tabular} & $\begin{array}{l}\text { Diğer } \\
\text { /Other }\end{array}$ & $\begin{array}{c}\text { Toplam/ } \\
\text { Total }\end{array}$ \\
\hline $\begin{array}{l}\text { Eğitim Fakültesi / } \\
\text { Faculty of Education }\end{array}$ & $\begin{array}{l}\text { Fakülte } \\
\text { içinde / } \\
\text { In faculty \% }\end{array}$ & $\% 44.4$ & $\% 7.4$ & $\% 21.0$ & $\% 4.9$ & $\% 6.2$ & $\% 16.0$ & $\% 100.0$ \\
\hline $\begin{array}{l}\text { Fen Edebiyat } \\
\text { Fakültesi / Faculty } \\
\text { of Arts and Sciences }\end{array}$ & $\begin{array}{l}\text { Fakülte } \\
\text { içinde / } \\
\text { In faculty \% }\end{array}$ & $\% 46.2$ & $\% 10.0$ & $\% 20.0$ & $\% 6.2$ & $\% 3.8$ & $\% 13.8$ & $\% 100.0$ \\
\hline $\begin{array}{l}\text { İktisadi ve İdari } \\
\text { Bilimler Fakültesi / } \\
\text { Faculty of Economics } \\
\text { and Administrative } \\
\text { Sciences } \\
\end{array}$ & $\begin{array}{l}\text { Fakülte } \\
\text { içinde / } \\
\text { In faculty \% }\end{array}$ & $\% 36.7$ & \%8.9 & $\% 17.7$ & $\% 10.1$ & $\% 6.3$ & $\% 20.3$ & $\% 100.0$ \\
\hline $\begin{array}{l}\text { Mühendislik } \\
\text { Fakültesi / Faculty } \\
\text { of Engineering }\end{array}$ & $\begin{array}{l}\text { Fakülte } \\
\text { içinde / } \\
\text { In faculty \% }\end{array}$ & $\% 47.5$ & $\% 10.0$ & $\% 16.2$ & $\% 7.5$ & $\% 2.5$ & $\% 16.2$ & $\% 100.0$ \\
\hline $\begin{array}{l}\text { Sağllk Bilimleri } \\
\text { Fakültesi / Faculty } \\
\text { of Health Sciences }\end{array}$ & $\begin{array}{l}\text { Fakülte } \\
\text { içinde / } \\
\text { In faculty \% }\end{array}$ & $\% 36.2$ & $\% 13.8$ & $\% 18.8$ & $\% 8.8$ & $\% 5.0$ & $\% 17.5$ & $\% 100.0$ \\
\hline Toplam / Total & $\begin{array}{l}\text { Fakülte } \\
\text { içinde / } \\
\text { In faculty \% }\end{array}$ & $\% 42.2$ & $\% 10.0$ & $\% 18.8$ & $\% 7.5$ & $\% 4.8$ & $\% 16.8$ & $\% 100.0$ \\
\hline
\end{tabular}

Öğrencilere "süt tüketmede ilk sebebiniz nedir?" sorusu yöneltilmiştir. Öğrencilerin \%42.2'si sütün besleyici özellikte olmasını ilk sebep olarak göstermiştir. Literatürdeki anket çalışmalarında süt tüketiminde ilk sebebiniz nedir sorusu üzerine ögrencilerin Durmaz vd. (2002) \%62.98'inin, Tarakçı vd. (2003) \%60.16’sının, Çetinkaya (2010) \%46’sının, Şimşek ve Açıkgöz (2011) \%59.7'sinin ve Yabanc1 Ayhan vd. (2018) \%55.2'sinin sütü besleyici özellikte olduğu için tükettiğini rapor etmişlerdir. Yapılan çalışmalar ve bu anket çalışması sonucunda sütün besleyici özelliğinin diğer parametrelere göre ön plana ç1ktı̆̆1 görülmektedir. 
Çizelge 7. Fakülteye göre katılımcıların "Süt tüketiminde karşılaştığınız başlıca problem nedir?” sorusuna verdikleri cevapların frekans ve yüzde dağılımları

Table 7. Frequency and percentage distributions of respondents, according to the faculty, to the question of "What is the main problem you face in milk. consumption?"

\begin{tabular}{|c|c|c|c|c|c|c|}
\hline & & $\begin{array}{l}\text { Sindirim } \\
\text { sorunu / } \\
\text { Digestive } \\
\text { problem }\end{array}$ & $\begin{array}{l}\text { Mide } \\
\text { bulantıs1 } \\
\text { / Nausea }\end{array}$ & $\begin{array}{l}\text { Tiksinme } \\
\text { sorunu / } \\
\text { Loathing }\end{array}$ & $\begin{array}{c}\text { Herhangi } \\
\text { bir sorunla } \\
\text { karş1laşm1- } \\
\text { yorum / No } \\
\text { problem }\end{array}$ & $\begin{array}{l}\text { Toplam } \\
\text { / Total }\end{array}$ \\
\hline $\begin{array}{l}\text { Eğitim Fakültesi / } \\
\text { Faculty of Education }\end{array}$ & $\begin{array}{l}\text { Fakülte içinde } \\
\text { / In faculty } \%\end{array}$ & $\% 2.5$ & $\% 6.2$ & $\% 8.6$ & $\% 82.7$ & $\% 100.0$ \\
\hline $\begin{array}{l}\text { Fen Edebiyat Fakültesi / } \\
\text { Faculty of Arts and Sciences }\end{array}$ & $\begin{array}{l}\text { Fakülte içinde } \\
\text { / In faculty } \%\end{array}$ & $\% 7.5$ & $\% 12.5$ & $\% 10.0$ & $\% 70.0$ & $\% 100.0$ \\
\hline $\begin{array}{l}\text { İktisadi ve İdari Bilimler } \\
\text { Fakültesi / Faculty of } \\
\text { Economics and Administrative } \\
\text { Sciences }\end{array}$ & $\begin{array}{l}\text { Fakülte içinde } \\
\text { / In faculty } \%\end{array}$ & $\% 8.9$ & $\% 12.7$ & $\% 11.4$ & $\% 67.1$ & $\% 100.0$ \\
\hline $\begin{array}{l}\text { Mühendislik Fakültesi / } \\
\text { Faculty of Engineering }\end{array}$ & $\begin{array}{l}\text { Fakülte içinde } \\
\text { / In faculty } \%\end{array}$ & $\% 7.5$ & $\% 16.2$ & $\% 5.0$ & $\% 71.2$ & $\% 100.0$ \\
\hline $\begin{array}{l}\text { Sağllk Bilimleri Fakültesi / } \\
\text { Faculty of Health Sciences }\end{array}$ & $\begin{array}{l}\text { Fakülte içinde } \\
/ \text { In faculty } \%\end{array}$ & $\% 12.5$ & $\% 7.5$ & $\% 6.2$ & $\% 73.8$ & $\% 100.0$ \\
\hline Toplam / Total & $\begin{array}{l}\text { Fakülte içinde } \\
\text { / In faculty } \%\end{array}$ & $\% 7.8$ & $\% 11.0$ & $\% 8.2$ & $\% 73.0$ & $\% 100.0$ \\
\hline
\end{tabular}

Öğrencilere "süt tüketiminde karşılaş̧ı̆̆ınız başlıca problem nedir?" sorusu yöneltilmiştir. Öğrencilerin \% 73 'ünün süt tüketiminde herhangi bir sorunla karşılaşmadığı belirlenmiştir. Çetinkaya (2010) yaptığı çalışmada, süt tüketimi esnasinda öğrencilerin \%74.5’inin herhangi bir sorun yaşamadığını rapor etmiştir. $\mathrm{Bu}$ yönüyle anket çalışmamız, Çetinkaya (2010)'un bulguları ile benzerlik göstermektedir. Durmaz vd. (2002) yaptıkları çalışmada sütü sevmeyen öğrencilerin \%32.98'i kokusu, \%34.04'ü tadı nedeniyle sevmediğini, Tarakç1 vd. (2003) sütü sevmeyen ögrencilerin \%23.60'1 kokusu, \%33.71'i tad1, $\% 13.48$ 'i alerjik rahatsızlı̆̆ı nedeniyle içmediğini belirtmişlerdir. Şimşek ve Açıkgöz (2011) ögrencilerin \%38.6's1 tadından, \%37.6's1 kokusundan, \%10.1'i ise alerjik vb. rahatsızlıklardan dolay1 süt tüketmediğini, Yabanc1 Ayhan vd. (2018) süt tüketmeyen öğrencilerin \%54.1'inin sütü sevmemesi, \%24.3'üne sütün dokunmas1, \%21.6'sının sütün kokusundan tiksinmesi nedeniyle içmediğini tespit etmişlerdir. Anket bulgularımız ile diğer çalışmalar arasında oranlar farklı olmasıyla birlikte genel bir benzerlik olduğu anlaşılmaktadır.

\section{SONUÇ}

Erzincan Üniversitesinde, 5 ayrr fakültede lisans eğitimi gören öğrencilerin süt tüketim alışkanlıklarının ve davranışlarının belirlenmesine yönelik yapılmış olan bu araştırmada öğrencilerin \%67'sinin sütü sevdiği ve haftalık kişi başına 1.3 litre süt tükettiği tespit edilmiş olup bu miktarın kişi başına yıllık 66 litreye tekabül ettiği 
belirlenmiştir. Gelişmiş ülkelerle kıyaslandığında, anket sonucu elde ettiğimiz verilerin ciddi oranda düşük olduğu görülmektedir. Öğrencilerin çoğunlukla sütü marketlerden aldığ1, genellikle temizlik ve hijyen koşullarının yetersiz olduğu bakkal ve pazarların tercih edilmediği belirlenmiştir. Anket verilerine göre öğrencilerin süt satın alırken markaya, fiyata, üretim ve son kullanma tarihine dikkat ettiği ve bu etkenlerin süt tüketimini etkilediği saptanmıştır. Sağlık Bilimleri Fakültesi öğrencileri haricinde diğer öğrencilerin genellikle süt ile bulaşan hastalıklar konusunda yeterli bilgiye sahip olmadığ1, öğrencilerin süt tüketmede ilk sebep olarak sütün besleyici özelliğini ön plana çıkardığı ve önemli ölçüde süt tüketiminde herhangi bir sorunla karşılaşmadığ tespit edilmiştir. Öğrencilerin genel olarak sütü sevmesine rağmen çeşitli nedenlere bağlı olarak yeterli miktarda süt tüketmediği görülmektedir. Öğrencilerin süt tüketme alışkanlıklarının arttırılması için, sütün sağlıklı ve dengeli beslenmedeki önemi ve günlük tüketilmesi gereken miktarı konusunda bilinçlendirilmeleri gerekmektedir. Çocukluk döneminden itibaren ögrencilere süt tüketimi alışkanlığ kazandırılmalı, bu amaç doğrultusunda 2011-2012 eğitim öğretim yllından itibaren ilkokul öğrencilerine uygulanan Okul Sütü Programı desteklenmelidir. Yine toplum sağlığı için süt ile bulaşan hastalıklar ve bu hastalıkların önüne geçilmesinde etkili olan 1s1l işlemler konusunda öğrenciler çeşitli eğitimlere tabi tutulmalıdır. Toplumu süt içmeye teşvik etmek için gazetelerde, dergilerde, seminerlerde ve diğer birçok alanda süt tüketiminin önemi reklam ve bilgilendirme yöntemiyle daha çok yer almalıdır. Süt üretimi desteklenmeli, soğuk zinciri kırmadan gereken mevzuata uygun süt satışları marketlerle sınırlı kalmamalı, süt satışları uygun fiyatlarda ve uygun ambalaj materyalleri kullanılarak yaygınlaştırılmalıdır.

\section{KAYNAKLAR}

Anonymous (2018). Okul Sütü Programı. http://www.okulsutu.com/dunyada-okul-sutu (Erişme Tarihi: 22 Temmuz 2018).

Arabacıoğlu Özbilen, Z. (1993). İçme Sütü Tüketiminin Arttrrılması ve Okul Sütü Programları. 5. Türkiye Sütçülük Kongresi, 20-21 May1s 1993, Ankara, Türkiye, 217 s.
ASÜD (2010). Dünya ve Türkiye Süt Endüstrisi Raporu. 1. Basım, Ankara, Türkiye.

Ayar, A., Demirulus, H. (2000). Eğitim Çağındaki Gençlerin Süt ve Süt Ürünleri Tüketim Alışkanlıklarının Belirlenmesi Üzerine Bir Araştırma. GID A, 25(5): 371-376.

Bıyıklı, E.T. (2011). Konya ili 10-15 yaş aralığındaki ilköğretim öğrencilerinde süt ve süt ürünleri tüketim alışkanlığı, laktoz sindirim güçlüğü ve intoleransı üzerine bir araştırma. Selçuk Üniversitesi Sosyal Bilimler Enstitüsü Çocuk Gelişsimi ve Ev Yönetimi Eğitimi Anabilim Dalı Beslenme Eğitimi Bilim Dalı Yüksek Lisans Tezi, Konya, Türkiye, $94 \mathrm{~s}$.

Black, R.E., Williams, S.M., Jones, I.E. (2002). Goulding, A.Children who avoid drinking cow milk have low dietary calcium intakes and poor bone health. Am J Clin Nutr, 76: 675-680.

Cevger, Y., Aral, Y., Demir, P., Sarı̈̈zkan, S. (2008). Ankara Üniversitesi Veteriner Fakültesi intern öğrencilerinde hayvansal ürünlerin tüketim durumu ve tüketici tercihleri. Ankara Üniv Vet Fak Derg, 55, 189-194.

Christopher, B.E., Nordin, N. (1997). Calcium and Osteoporosis. Nutrition, 13: 718.

Collins, M. (1986). Sampling, consumer market research handbook country of origin labeling, $J$. Agr. Appl. Econ., 37(1): 49-63.

Çapraz, İ., Yılmaz, V. (2005). İstanbul ticaret odası kobi araştırma ve geliştirme şubesi, süt ve süt ürünleri sektör profili. http://www.ito.org.tr/Dokuman/Sektor/185.pdf (Erişim tarihi: 7 Nisan 2017).

Çetinkaya, A. (2010). Kafkas üniversitesi öğrencilerinin içme sütü ve süt ürünleri tüketim alışkanlıklarının belirlenmesi. Atatürk Üniversitesi Vet. Bil. Derg., 5(2): 73-84.

Durmaz, H., Sağun, E., Tarakçı, Z. (2002). Yüksekokul öğrencilerinin içme sütü tüketim alışkanlıkları. YYÜ. Vet. Fak. Derg., 13(1-2): 6973.

Hasipek, S., Aktaş, N., Sürücüoğlu, M.S. (1988). Konya Selçuk Üniversitesi Ziraat Fakültesi Öğrencilerinin Süt ve Süt Ürünleri Tüketim Sıklığ1 
ve Bunu Etkileyen Faktörler. GIDA, 13(2): 99106.

Heaney, R.P., McCarron, D.A., Dawson-Huges, B., Oparil, S., Berga, S.L., Stern, J.S., Barr, S.I., Rosen, C.J. (1999). Dietary Changes in Favourably Affect Bone Remodeling in Older Adults. J Am Diet Assoc, 99(10): 1128-1133.

IBM Corp. Released 2011. IBM SPSS Statistics for Windows, Version 20.0. Armonk, NY: IBM Corp.

Jain, M. (1998). Dairy Foods, Dairy Fats, and Cancer: A Review of Epidemiological Evidence. Nutr Res, 18(5): 905-937.

Karagözlü, N., Karagözlü, C., Karaca, S., Eren, S. (2005). Üniversite öğrencilerinde süt ve ürünleri tüketim alışkanlıkları ve beslenme bilinçleri üzerine bir araştırma: Celal Bayar Üniversitesi Mühendislik Fakültesi örneği. Celal Bayar Üniv. Fen Bilim. Derg., 1(2): 101-108.

Manaf, Z.A., Lee, M.T., Ali, N.H.M., Samynathan, S., Jie, Y.P., Ismail, N.H., Yong, B.H.Y., Yeo, W.S., Yahya, N.A. (2012). Relationship between Food Habits and Tooth Erosion Occurrence in Malaysian University Students. Malays J Med Sci, 19(2): 56-66.

Metin, M. (2014). Süt Teknolojisi-Sütün Bilessimi ve İslenmesi. Ege Üniversitesi Basımevi, İzmir, Türkiye, $802 \mathrm{~s}$.

Miller, G.D., Jarvis, K.J., McBean, L.D. (2000). The Importance of Milk and Milk Products in the Diet. In: Handbook of Dairy Foods and Nutrition, Jensen, R.G., Kroger, M. (ed.), Second Edition, CRC Press, the USA, pp. 4-24.

Para, G., Ülger, İ., Kaliber, M. (2018). Erciyes Üniversitesi öğrencilerinin süt tüketim alışkanlıklarının belirlenmesi üzerine bir araştırma. Iğdır Üni. Fen Bilimleri Enst. Der., 8(1): 329-339.

Stefanikova, Z., Sevcikova, L., Jurkovicova, J., Sobotova, L., Aghova, L. (2006). Positive and negative trends in university students' food intake. Bratisl Lek Listy, 107(5): 217-220.

Şahinöz, S., Özdemir, M. (2017). Üniversite öğrencilerinin süt ve süt ürünleri tüketim alışkanlıkları ve etkileyen faktörler. Gümüshane Üniversitesi Sağlk Bilimleri Dergisi, 6(4): 106-112.

Şeker, İ., Şeker, P., Şahin, M., Özen, V.S., Akdeniz, A., Erkmen, O., Kışlalıoğlu, İ., Sargın, G., Doğu, G.B. (2012). Elazı̆̆ İli Merkez İlçede Tüketicilerin Süt Tüketim Alışkanlıkları ve $\mathrm{Bu}$ Alışkanlıkları Etkileyen Faktörlerin Belirlenmesi. F.Ü.Să̆.Bil.Vet.Derg., 26(3): 131-143.

Şimşek, B., Açıkgöz, İ. (2011). Süleyman Demirel Üniversitesi öğrencilerinin içme sütü tüketim alışkanlıklarının belirlenmesi. YYÜ TAR BIL DERG, 21(1): 12-18.

Tarakçı, Z., Selçuk, Ş., Şahin, K., Coşkun, H. (2003). Üniversite öğrencilerinin içme sütü tüketim alışkanlıkları üzerine bir araştırma. YYÜ TAR BILL DERG, 13(1): 15-21.

Topcu, Y. (2006). Süt Ürünlerinde Marka Rekabeti ve Tüketici Davranişlari: Erzurum İli Örneği. Atatürk Üniversitesi Fen Bilimleri Enstitüsü Tarım Ekonomisi Anabilim Dalı Doktora Tezi, Erzurum, Türkiye, 277 s.

Tönük, B., Gültürk, H., Güneyli, U., Arıkan, R., Kayim, H., Bozkurt, Ö. (1984). Gıda Tüketimi ve Beslenme Araştırması. Ankara: Tarım, Orman ve Köyişleri Bakanlığ1/ UNICEF, Koruma Kontrol Genel Müdürlüğ̈̈; 1987.

Uzunöz, M., Gülşen, M. (2007). Üniversite öğrencilerinin süt ve süt ürünleri tüketim alışkanlıklarının belirlenmesi. Gıda Teknolojileri Elektronik Dergisi, 3: 15-21.

Ünal, R.N., Besler, H.T. (2008). Beslenmede Sütün Önemi. Klasmat Matbaacılık, Ankara, Türkiye, 37 s.

Weinberg, L.G., Louse, A., Berner, Grones, J.E. (2004). Utrient Contributions of Dairy Foods in the United States, Continuing Survey of Food Intakes by Individuals 1994-1996, 1998. J Am Diet Assoc, 104: 895-902.

Yabanc1 Ayhan, N., İplikçi, G., Şimşek, I. (2018). Üniversite öğrencilerinin süt ve süt ürünleri tüketimi üzerine bir araştırma. Akademik Sosyal Arastirmalar Dergisi, 6: 370-380. 